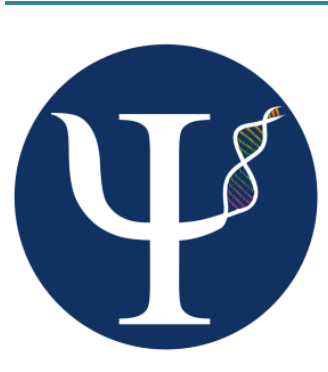

\title{
Paradoxical Personality Scale: Its Development and Construct Validity Analysis
}

\section{Escala de Personalidad Paradójica: Desarrollo y Análisis de Validez de Constructo}

\author{
Agustín Freiberg Hoffmann ${ }^{\text {a, } *, \varpi, ~ G u a d a l u p e ~ d e ~ l a ~ I g l e s i a ~}{ }^{\text {b, c, }}$, \\ Juliana Beatriz Stover ${ }^{a}$, , and Mercedes Fernández Liporace ${ }^{\text {b, }}$, $\square$

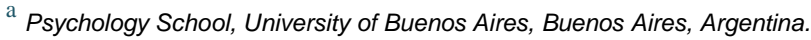 \\ ${ }^{\mathrm{b}}$ Psychology School, University of Buenos Aires, Buenos Aires, Argentina. \\ ${ }^{\mathrm{c}}$ National Council of Scientific and Technological Research (CONICET), Buenos Aires, Argentina.
}

Res e a rch

CNalional Council or Scientific and Technological Research (CONCET), Buenos Aires, Argentina.

\section{ARTICLE INFO}

\begin{abstract}
The development and construct validation process of the Paradoxical Personality Scale is presented in this paper. The concept assessed has been posed by Csikszentmihalyi (1996) and was described as related to creative individuals. Following his guidelines, 150 items were designed and judged by five experts, and later analysed from a facies standpoint. The resulting version was used in a sample of college students ( $n=473 ; 50.5 \%$ males, $49.5 \%$ females) from 18 to 35 years ( $\bar{X}=$ 21.82; $D T=3.14$ ), to explore underlying dimensions. A 30item/6-factor solution was firstly isolated and after confirmed by a confirmatory factor analysis developed with 800 college students $(44.4 \%$ males, $55.6 \%$ females), between 18 and 35 years $(\bar{X}=$ 23.47; $D T=3.30$ ). Both samples were selected from the population of college students from Buenos Aires, Argentina. Internal consistency and temporal stability of scores were also tested, obtaining adequate coefficients in both cases, in view of the composition of the dimensions underlying the construct analysed. Results show acceptable psychometric properties as well as shortness and simplicity for data gathering, which are discussed taking into account theoretical models and new research lines.
\end{abstract}

\section{RESUMEN}

Se presenta el proceso de construcción y validación de la Escala de Personalidad Paradójica, diseñada a partir de la propuesta de Csikszentmihalyi (1996), quien describiera el concepto evaluado en relación a los individuos creativos. Se redactaron 150 reactivos que fueron sometidos a juicio experto y a examen de validez aparente en un estudio piloto. La versión resultante fue usada en un estudio factorial exploratorio (473 estudiantes; $50.5 \%$ varones, $49.5 \%$ mujeres; 18 a 35 años; $\bar{X}=21.82 ; \mathrm{DT}=3.14)$. La estructura resultante, de 6 dimensiones y 30 ítems, fue

Article history:

Received: 02-12-2013

Revised: 15-03-2014

Accepted: 01-04-2014

Key words:

Creative personality, paradoxical personality, college students, construct validity, reliability.

\footnotetext{
* Corresponding author: Agustín Freiberg Hoffmann. Psychology School, University of Buenos Aires. Argentina. Address: Secretaría de Investigaciones, Facultad de Psicología (UBA): Gral. Juan Lavalle 2353 C.A.B.A. (Argentina). CP: C1052AAA. Telephone/ Fax: 4952-5481 / 5490. Email address: afreiberg@psi.uba.ar
} 
confirmada mediante un análisis factorial confirmatorio (800 estudiantes universitarios; $44.4 \%$ varones, $55.6 \%$ mujeres; 18 a 35 años; $\bar{X}=23.47$; DT $=3.30$ ). Ambas muestras provenían de la población de estudiantes universitarios de Buenos Aires, Argentina. También se analizó la consistencia interna y la estabilidad temporal de las puntuaciones, obteniéndose en ambos casos coeficientes aceptables, dada la composición de las dimensiones subyacentes al constructo analizado. Se discuten los resultados a la luz de los modelos teóricos propuestos, las ventajas de la brevedad y sencillez de aplicación y según nuevas líneas de investigación. personalidad

paradójica,

estudiantes

universitarios, validez

de constructo,

fiabilidad.

\section{INTRODUCTION}

The XXI century, distinguished by a fast information exchange, generates a huge increase in productivity, proposing cultural transformations, involving impressive changes in techniques, ways and spaces of communication. These changes produce modifications in people's everyday life, introducing dramatic variations in habitual rhythms, with impact on behaviors, reasoning and attitudes as well (Mayans, Tubella \& Casadeval, 2005). Facing the situation described before, universities assume the challenge of offering an integral education in order to get graduates capable to solve concrete issues in each professional field. Considering that, besides strictly academic knowledge, students must be trained in the development of certain abilities -such as evaluation, analysis, critical reasoning, problem solving strategies, organisation and referencing capacities, synthesis, decision making towards incomplete information, communication in different ways-, where creativity can also be placed (Treffinger \& Selby, 2008). College education, taken into account with some other factors such as hereditary, cognitive, personality traits, environmental and technical, contribute to develop this perfectible capacity linked to professional activities. Its importance is mainly based on the fact that the ability to apply new solutions to problems of specific disciplines -arts, science and literature, for instancedepends strictly on the type of instruction received, which offers new and valuable knowledge to the individual who works in a particular field of specialization (Csikszentmihalyi, 1996).

The aforementioned pursued involvement of academic institutions aforementioned is highlighted by international organisations, such as UNESCO (1998) and CEPAL (2011). They strongly support this viewpoint and stress the role of creativity in superior education. UNESCO emphasizes that students must be trained in the types of reasoning which include creativity, intending the acquisition of enough expertise to manage their own learning processes at graduation time. Meanwhile, CEPAL states that the increasing incorporation of new information and communications technologies (ICTs) to teachinglearning environments requires educational policies oriented to develop these capacities in students.

All these aspects enable designed researches to examine learning processes in order to describe its behavior in academic situations (e.g. Almansa \& López, 2010; Batey, Chamorro \& Furnham, 2010; Clapham, 2004; Elisondo \& Donolo, 2010; Getzels \& Jackson, 1962; López \& Brufau, 2010; Naderi, Abdullah, Aizan, Sharir \& Kumar, 2010; Pérez \& Campos, 2007). The main goal rests not only in the comprehension of the way in which this complex phenomenon takes place, but also in identifying the aspects that could facilitate or inhibit its development.

From this approach, this study intends to describe this behaviour concept in a sample of students from the high level of the educational system, posing two main goals. The first one aims to the comprehension concept from a theoretical viewpoint, and the second involves the generation of a new scale to assess it. Thus, descriptive results for creativity in each field or career would allow specific educational planning, regarding pedagogical strategies to improve this trait in college students.

\subsection{Assessing creativity}

Psychometric assessment of the concept locates its origin in pioneering ideas of Guilford (1977), who asserted the existence of two kinds of thinking. In one hand, convergent thinking is related to individual's background knowledge; divergent thinking, in the other hand, is represented by the ability to use this background knowledge with enough proficiency to produce novel ideas, being that a mental operation. Furthermore, Guilford proposed four main factors fluency, flexibility, originality, elaboration- integrating divergent thinking; these factors underlie to operative measuring by means of psychometric scales. While this traditional assessment of creativity is focused in the process dimension, new approaches consider that its study cannot be restricted to this unique dimension. For this reason, a multidimensional model to describe 
this ability as a complex phenomenon to be studied from diverse categories was proposed. One of the most popular typologies in force presents four main dimensions, such as process, product, environment and person (e.g. Csikszentmihalyi, 1996; de la Torre, 2006; Gardner, 1997; Pascale, 2005; Simonton, 2003).

As for the process, cognitive aspects which participate actively in problem solving activities are studied, standing out the dimensions which integrate divergent thinking -fluency, flexibility, elaboration, originality-. They were employed as a basis for classic scales, such as Divergent Thinking Test (Guilford, 1950) and TTCT - Torrance Test of Creative Thinking (Torrance, 1966), which were widely used in investigations and academic institutions. Regarding products analysis, it is linked to productivity or results valuation. It is carried out by means of psychometric tests, and by expert judges as well, who establish criteria to define what is considered creative and what does not deserve this label. Taking the environment, contextual sources potentially beneficial for the development of that quality are examined, as for instance educational or familial milieu. Finally, the analysis of the person is focused on those intellectual and personality traits directly related to the degree of creativity of each individual.

This last dimension and process consider the greater amount of psychometric research due to the two remaining dimensions -product and environmentshow major obstacles to their assessment. Firstly, difficulties to reach a gold standard to establish the degree of creativity implied in different productions must be considered. Secondly, the diversity of environmental factors potentially influential in the configuration of individual creative traits has to be spotlighted as an issue of interest (López, Corbalán \& Martínez, 2006).

From the most studied group, the process has been the component more frequently analysed, while the person - here defined as the configuration of personality attributes, speaking in general termsaccounts less research developments. The person approach is, precisely, the one which will allow an accurate identification of ideas and behaviors of creative people. Examining consistency and stability of personal components, together with the discrimination of individual differences in these traits appear as main goals for future research (Feist, 1998).

\subsection{Personality and creativity}

The notion of personality involves a group of attributes which are supposed to be an expression of how a given person feels, thinks and acts, putting on the table the idea of regular patterns of behavior that emerge under certain circumstances (Pervin \& John, 2000). Departing from this definition, the aim consists in the detection of some stable qualities, suitable for predictions within different individuals who will be those whose productions could be classified as creative. Taking into account this criterion, two traditional methodologies to examine this phenomenon are possible. Firstly, the study of the relationship between different traits of personality which appear in a remarkable degree -extroversion, introversion, opening to experience, neuroticism, gregariousness, etc.- and the individual's ability to find novel solutions to a given problem (e.g. Chacón \& Moncada, 2006; Limiñana, Corbalán \& Sánchez, 2010; Sanz de Acedo Baquedano \& Sanz de Acedo Lizarraga, 2012). Second, the detection of traits considered inherent to creative people -such as artistic inclination, tolerance for ambiguity, initiative, curiosity, ambition and need for originality (e.g. Karwowski, 2012; Martinsen, 2011; Merrotsy, 2013). Both approaches constitute two classical ways of understanding creative personality, and they include, consequently, scales to measure its dimensions.

In a separate line, a different view asserts that the concept is identified by the simultaneous presence of multiple antagonistic traits. Their integration in an individual's personality increases its degree of complexity, resulting this in the possibility of proposing this relationship as directly proportional to creative ability (e.g. Csikszentmihalyi, 1996; Giovacchini, 1991; Maslow, 1973).

Next, some important aspects from the traditional approach are briefly described, following after that with main ideas about creative personality, defined as a complex phenomenon.

\subsection{Creative personality: Traditional perspective}

As mentioned before, research on creative personality is traditionally focused on describing some traits which appear frequently in that kind of individuals. Classic profiles described by Guilford (1950) and Lowenfeld (1979) are composed of qualities such as sensitivity, receptivity, a huge capacity of adaptation to new facts, originality, ability to modify the function or purpose of a given object, capacity for synthesis, as well as an appropriate expressivity for the transmission of a big amount of information using very few resources.

From a contemporary view, Davis (1989) poses that this kind of people is distinguished by being aware about this attribute in themselves, for being 
independent, by the possession of high levels of energy, by a refined perception, by the assumption of risks, by being curious, by being good mood people, by having an open mind and artistic sense, by appreciating loneliness, and by feeling attraction towards innovations and complexity. Furthermore, Eysenck (1995) emphasizes as a distinctive quality their huge degree of psychoticism -attribute shared with psychotic patients-, which would allow creative people to produce a big amount of ideas and associations in a short period of time, by means of the cognitive mechanism of overinclusion, which is feasible because of the lack of cognitive inhibition.

Rogers and Freiberg (1996) draw attention to their self-confidence, their open mind, their lack of conformism and, occasionally, their lack of cultural adaptation. Finally, Gardner (1997) describes their high motivation and the ability of expression by symbolic means, as well as the adequate tolerance to frustration and to uncertainty, and a strong perseverance. Some of their major notes consist in the assumption of risks without feeling fear to failure and an extraordinary tendency towards social activities.

In the other hand, current research points up the effects of traits such as extraversion, consciousness and emotional stability on creativity, explaining $43 \%$ of its variance. Besides, another complementary attributes could be taken into account, such as the disposition to overcome obstacles, tolerance to ambiguous conditions, self-efficacy and self-discipline, ability to become valuable objects and situations apparently inconsequential, etc. Every capacity listed before requires breaking up with conventions and challenging majority opinions (e.g. Esfahani, Ghafari, Emami \& Baboli, 2012; Kaufman, 2009; Runco \& McGarva, 2013; Sternberg, 2006).

Thus, as it can be appreciated, the descriptions on creative personality given before contemplate a group of attributes -perceptive, cognitive, attitudes, interests and motivationscurrently in force, presenting a wide diffusion, explaining creative people' behaviour. However, at the same time a cautious attitude must be assumed towards the attempt to get consensus for a unique amount of qualities to describe this type of personality because of the well known objection to identify a homogeneous group of them in all creative individuals (Helson, 1996).

\subsection{Creative Personality: A Complex Perspective}

This approach had its origin in a series of case-studies which recorded as a common trait in creative people the ability to modify their actions, allowing them adopting antagonistic attitudes in completely different circumstances. In this way, these people become capable to locate regularities in behaviors, not only in stable traits, buy also in the complex antithetical dynamics that remains under them and the direct relationship between the complexity of personality -represented by the number of paradoxical or contradictory traits present in a given individual - and the degree of creativity that he possesses, is being posed, leaving aside the notion of a creative profile. Thus, it replaces the notion of a creative-adult-configuration consisting of unchanged or immovable characteristics by the notion of the coexistence of opposite tendencies and thoughts, which in common people are not simultaneous (Haller \& Courvoisier, 2010). Maslow (1973) can be distinguished as the stronger precursors of these ideas. He proposed this coexistence as a resolution of dichotomies, foregrounding some antithetical pairs, such as altruism-hedonism, instinct-reason, dutypleasure and work-play, etc. This logic, when moved to other areas in everyday life, can be applied by the most capable people to their own field of specialization. For instance, an artist could be capable to combine opposite colours or shapes which will be incompatible to common people.

McMullan (1976) also claims the conflict between traits, posing eight complementary pairs: delay closure, converging divergence, mindless perception, constructive discontent, detached involvement, disinterested selfishness, confident humility and relaxed attention.

After these initial concepts, Csikszentmihalyi (1996), names this coexistence as paradoxical personality. In a comprehensive case-study, he gets the description of ten pairs of traits, supposedly incongruent, with presence in the majority of individuals defined as creative people. Despite the author avoids labelling those pairs, the exam of their descriptions permits an attempt in this direction, as follows: Hyperactivity - Hypoactivity (energetic control), Rationality - Intuition, Responsibility Irresponsibility, Imagination - Reality, Extroversion Introversion, Humility - Pride, Masculinity - Femininity (Androgyny), Conservatism - Iconoclasm, Objectivity - Subjectivity (Passion), Suffering - Pleasure. It is important to note that this is a mere try and it could be modified in future revisions. Table 1 resumes the main behavoiral characteristics of each dimension.

Not every opposite polarity appears mandatorily in the same person, being able to appear only in some of them. Evenly, the possibility of considering some other trait not contemplated in 
Csikszentmihalyi's reasearch must be reasonably taken into account.

Interpreting empirical results according to theories allows to come up with the following hypothesis: human beings have initially a multiplicity of qualities, apparently antithetical. Some of them become fixed in most of people, while some others are atrophied throughout the life cycle, thus getting expression only one pole of this dialectical process. Creative people, differentiated from the rest, stand out for their ability to preserve both poles, being capable to express a wide variety of notes in diverse situations, and that is where the paradoxical and complex character of their personality comes from (Csikszentmihalyi, 1996).

The concept of paradoxical personality alludes, therefore, to a new way of comprehension of creative personality, focusing assessment in the number of contradictory traits present in each person. That is why, the more antithetical characters coexist within the same individual, the more complex his/her personality will be, and thus greater creativity will exist.

Table 1. Summary of paradoxical personality dimensions, following Csikszentmihalyi (1996).

Dimension

Hyperactivity - Hypoactivity

Rationality - Intuition

Responsibility - Irresponsibility

Imagination - Reality

Extroversion - Introversion

Humility - Pride

Masculinity - Femininity

Conservatism -Iconoclasm

Objectivity - Subjectivity

Suffering - Pleasure

\section{Description}

People who are very energetic sometimes, and silent and quiet some other times. They are able to work a huge amount of hours continuously having later long pauses to rest. They think that certain level of activity must be followed by periods of leisure and reflection.

Can be described as smart and sharp in some periods, and as extremely naive in others. This ingenuity facilitates curiosity, an essential component to develop every novel activity; but, in the other hand, astuteness and a high IQ generate self-satisfaction, self-confidence and feelings of mental superiority, trait equally relevant for creative activity. They are rigid and, at the same time, flexible people.

Linked with the ability to judge and maintaining discipline at the same time. The ludic character of the novel production goes with its antithesis, considering tenacity, strength and perseverance.

This trait belongs to those who have fantastic ideas, but with a strong support in reality. This goes with mental models which have, at least, a minimal connection with some aspects of reality.

Related with enjoying for being in the crowd or, instead, being apart and in expectancy. Creative people use to revise, listen to or exchange ideas with other people, and they also can bear loneliness, which is necessary during this process.

These people use to be self-critical and shy, but in some moments they become arrogant and they show disdain. This polarity also manifests as ambition - disinterest, or as competition cooperation. They are ambitious and aggressive subjects, but they can also be willing to subordinate their own projects and goods to somebody else's sake.

This trait refers to an escape from the stereotyped male and female models. Women behave in a dominant way, while men are more sensitive and behave in a less aggressive mode.

This pair can also be represented as rebellion versus traditionalism. Creative products require a certain knowledge and acceptance of values, uses and cultural productions that will be transgressed. Rebellion and traditionalism are necessary for creative process, since being only conservative leaves the field unmodified; and testing chances continuously without reference to what has been valued in the past rarely goes to a novel product conceived as a finished production.

This pair refers to an attached behavior versus an unattached attitude regarding the own production. Interest is soon lost without the help of passion when the task is hard. But if the person cannot be objective towards that task, the product will not be good or will show a lack of credibility.

Opening and sensitivity in creative people generally expose them to suffering and pain, but also to pleasure. They have a low pain threshold. Thus, when a creative person has been dedicated for years to a given work, or a scientist to design some device, it is devastating to them when they notice no interest from others. Oppositely, pleasure experienced when they can proceed with freedom is remarkable. 
As developing creativity in college contributes to professional achievement, research regarding its multiple dimensiones becomes relevant, particularly considering the notion of paradoxical personality. Given the abscense of instruments specifically designed to asssess this variable, the pursued goal consists in its development in order to measure this set of traits in a valid and reliable way (Benlliure, 2006). Keeping this in mind, results obtained from the development process, as well as exploratory and confirmatory analyses to provide evidences of construct validity are exposed. Reliability studies, carried on in a sample of Argentinean college students, are also reported.

Expectations rest, in this case, in offering this new short scale to psychologists who work in educational institutions to provide valuable information on this aspect related to creativity, potentially important in learning processes.

\section{METHOD}

\subsection{Design}

A psychometric, correlational-explicative, transversal design was developed (Gorsuch, 1983; Nieto \& Rodríguez, 2010).

\subsection{Participants}

Content and Facies Validity Study: 5 expert judges were asked to assess item-contents according to the theoretical model -3 experts in psychometrics and 2 artists-; 40 college students for the pilot study.

Construct Validity Study: 2 independent samples of college students from Buenos Aires, Argentina, were selected by means of two intentional simple sampling procedures, one for the exploratory factor study and the other for the confirmatory factor study. The criteria used to include participants in the sample were the following: first, every participant had to be attending to classes in college at the moment of the assessment; second, their ages must be between 18 and 35 years, interval which concentrates most part of student population in college level (Ministerio de Educación, 2011). Cases with incomplete answers were excluded, taking this attitude as a possible lack of interest towards the activity, which could affect the internal validity of the research.

Exploratory factor study: 473 students $(50.5 \%$ males, $49.5 \%$ females), who were from 18 to 35 years old $(\bar{X}=21.82 ; D T=3.14)$, from public $(73.8 \%)$ and private universities $(26.2 \%)$, attending diverse careers (23\% Psychology, 22.6\% Communication Sciences, $21.1 \%$ Engineering, 15.4\% Maths and Biology, 5.5\%
Social Sciences, 4.4\% Laws, 3.8\% Musical and Sound Arts, $3.6 \%$ Economics, $0.4 \%$ Philosophy and Literature) were included.

Confirmatory factor study: 800 students (44.4\% males, $55.6 \%$ females), between 18 and 35 years old $(\bar{X}=23.47 ; D T=3.30)$, who attended to different careers of public $(94.5 \%)$ and private $(5.5 \%)$ universities (24.6\% Psychology, 21\% Engineering, $19.5 \%$ Maths and Biology, $11.3 \%$ Laws, $6.9 \%$ Philosophy and Literature, 6.4\% Medicine, 5.5\% Economics, 4.8\% Musical and Sound Arts).

The sample size responds to recommendations concerning psychometric quality evaluations, which require at least 5 individuals for every item to be analysed (e.g. Gorsuch, 1983; Hatcher, 1994).

Reliability Test-retest Study: 36 students of Psychology $(22.2 \%$ males and $77.8 \%$ females $)$, from 21 to 46 years $(\bar{X}=26.08$; $D T=5.58)$.

\subsection{Instruments}

Following Csikszentmihalyi (1996) (rational criterion), a new scale to assess 10 styles composing paradoxical personality -Hyperactivity/ Hypoactivity, Rationality/ Intuition, Responsibility/ Irresponsibility, Imagination/ Reality, Extroversion/ Introversion, Humility/ Pride, Masculinity/ Femininity, Conservatism/ Iconoclasm, Objectivity/ Subjectivity and Suffering/ Pleasure- was developed. Each initial item (15 for each dimension, totalizing 150) consisted in an affirmation integrating simultaneously two contradictory attributes in order to portray the paradoxical trait assessed with the best possible accuracy. This way, examinees were asked to respond to each proposition according to their agreement whit it, regarding the whole sentence and not only one single part. A 5-point-likert scale was employed, where 1 represented the less possible agreement and 5, the maximum degree of accordance.

An additional questionnaire to gather personal and academic information - sex, age, type of university (public or private) and career- was also used to describe both samples.

\subsection{Procedures}

Content and Facies Validity Study: The 5 experts received an instructive containing some guidelines to carry on their evaluation, including a brief theoretical summary, the description of each dimension and some directions to complete the task requested. Besides, a booklet with the original 150 
items randomly organized was delivered. Two scales were also included, where the experts must indicate, firstly, to what dimension every item belonged -in accordance with his/her criterion-, and secondly, the quality of the item measured by a scale form 1 to 7 , where 1 represented not adequate and 7, extremely adequate (Moreno, 2000). Once the step above described was completed, a shorter version of the scale was achieved, which was composed by the remaining items. Then, item comprehension was examined by a pilot study carried on with 40 students, getting some suggestions for linguistic adjustments. Besides, the ambiguous character of the sentences was pointed out by several participants.

Construct Validity and Internal Consistency Studies: Two samples of data were gathered, one for the exploratory factor analysis of the resultant scale form the studies of content and facies validity referred above, and another one for the confirmatory factor analysis, where a shorter and refined version was used as a consequence of exploratory analysis. Both procedures were developed during the regular class schedule by a licensed and properly trained psychologist,with the voluntary participation of the respondent students without economic retribution and by signing an informed consent. Confidentiality of results and anonymity of personal data was assured in every moment allowing the possibility of interrupting the response whenever the student would decide it. This study was supported by institutional endorsements.

Test-retest Reliability Study: The scale was responded twice by the same examinees with a separation of 30 days between every session.

\subsection{Data Analysis}

Content Validity Study: A software development, designed with Visual Basic software (Merino, Soto \& Livia Segovia, 2009), to calculate Aiken's V coefficient was utilized (Aiken, 1985).

Construct Validity Study: Packages of software which allowed the proper statistical treatment of data gathered by polytomous scales were used both for principal components analysis (PCA) and for confirmatory factor analysis (CFA) (Manzano \& Zamora, 2009; Richaud, 2005). For PCA, FACTOR 8 (Lorenzo \& Ferrando, 2012) was employed. LISREL 8 (Scientific Software International, 2006) was run for CFA.

Internal Consistency: In order to estimate internal consistency, FACTOR 8 (Lorenzo \& Ferrando, 2012) was also employed; this package calculates ordinal alpha coefficients, not for the observed variables, but the latent variables supposed to be continuous. This way, internal consistency is weighted departing from the relationship between the answers to every item and its underlying variable. This procedure resembles the idea of modelization for ordinal variables, adding the invariance of estimations as main benefit due to their independence from the number of categories of the scales because of their obtainment from the latent variables (Elosua \& Zumbo, 2008).

Test-retest Reliability Study: Due to the compliance of assumptions required to calculate parametric tests, stability of scores from the first and the second assessment was examined by Pearson's $r$ coefficient, employing the package SPSS 21 (IBM Corporation, 2012).

\section{RESULTS}

\subsection{Content and Facies Validity Studies}

As for the content analysis, a previous study (Freiberg Hoffmann, 2012) showed the agreement of judges about 92 of the 150 items developed, assuming as criterion a minimum of three experts according to retain that item plus an Aiken's V coefficient over .60. It should be highlighted that this index is used to quantify evidences of content validity, varying between 0 and 1 , meaning 0 a nil conformity, and being 1 the highest possible consensus referred to a given item content (Merino et al., 2009).

As an additional result, the expert judgement suggested by majority accordance to change some items form their original dimension to another in view of their content. Table 2 summarizes that moving for the cases where it was recommended.

In order to analyze evidences of facies validity, a sample composed of 40 college students responded the so far resulting version of 92 items, which were presented in a random order. The standard assumed to propose modifications consisted in at least 4 students $(10 \%$ of the sample) according to the the same suggestion. This way, just a unique consensual suggestion of linguistic type stayed in force: it was particularized in the replacement of an expression. Moreover, 15 students pointed out the ambiguity of sentences, observation which was recorded but not executed modifying that note in order to prior item representativeness regarding the paradoxical quality inherent to dimensions. 
Table 2. New distribution by dimensions for some items as it was recommended by expert judges.

Item

Siento que soy bastante autosuficiente, aunque reconozco que por momentos necesito pedir ayuda por cuestiones que escapan a mi conocimiento.

20 Muchas veces me apego por completo a las normas, pero muchas otras las transgredo.

En ciertas circunstancias me siento superior a los demás, pero en otras me siento demasiado inferior.

28

Cuando tengo que resolver algún problema suelo usar tanto ideas que ya he adquirido, como ideas nuevas que fluyen por mis pensamientos

29 Suelo aferrarme fuertemente a ciertas ideas mías y suelo dejar ir otras.

32

Suelo ser, en ocasiones, bastante conservador en la realización de algunas actividades y muy arriesgado en otras.

36

Suelo explorar nuevas ideas mediante ensayo y error, aunque a veces prefiero hacer las cosas del modo más conocido y estándar posible.

42

Cuando se me mete una idea en la cabeza por más disparatada que parezca insisto mucho hasta conseguir aplicarla.

43 Cuando tengo que hacer algo me olvido del tiempo pero siempre lo termino.

44

Si bien no me importa cuánto tardo en terminar una actividad, debo confesar que suelo trabajar hasta altas horas de la noche.

52

Por momentos intento crear nuevas realidades, pero otras veces prefiero quedarme cómodo en esta realidad preexistente.

59

Mi lectura de la realidad si bien muchas veces me lleva por caminos equivocados, muchas otras veces me llevan a prever hechos relevantes.

77

Generalmente soy bastante tímido, pero por momentos soy bastante desdeñoso.

104

Si bien me suelo preocupar por mi entorno muchas veces me centro sobre mi persona.

Original dimension for the item

Rationality - Intuition

Rationality - Intuition

Rationality - Intuition

Rationality - Intuition

Rationality - Intuition

Responsibility

Irresponsibility

Responsibility -

Irresponsibility

Responsibility -

Irresponsibility

Responsibility -

Irresponsibility

Responsibility -

Irresponsibility

Imagination - Reality

Imagination - Reality

Humility - Pride

Masculinity -

Femininity

Suffering - Pleasure

Suelo molestarme muy fácilmente
soy extremadamente tolerante.
Dimension suggested by Judges

Humility- Pride

Conservatism-

Iconoclasm

Humility - Pride

Conservatism Iconoclasm

Objectivity -

Subjectivity

Conservatism Iconoclasm

Conservatism -

Iconoclasm

Imagination - Reality

Hyperactivity -

Hypoactivity

Hyperactivity Hypoactivity

Conservatism -

Iconoclasm

Rationality - Intuition

Extraversion Introversion

Extraversion Introversion

Masculinity -

Femininity

Note. Original items were randomly numbered from 1 to 150 . After content validity and construct validity studies, numbers were changed replacing eliminations. This table contemplates the original sequence. 


\subsection{Construct Validity Study}

\subsubsection{Exploratory Factor Analysis}

A principal components analysis was developed, trying diverse solutions, forcing the extraction to 10 factors, and intending to reproduce empirically the theoretical structure proposed by Csikszentmihalyi (1996). After several exams it was observed that those items belonging to dimensions such as Rationality-Intuition, ResponsibilityIrresponsibility, Masculinity-Femininity and ObjectivitySubjectivity were related in an inconsistent way to the model, which distorts the integrity of results. In order to improve psychometric quality, the decision of keeping the complete pool of items seemed the most sensible course of action, forcing now the extraction to 6 factors to evaluate if the remaining dimensions (Hyperactivity-Hypoactivity, Imagination-Reality, Extroversion-Introversion, Humility-Pride, Conservatism-Iconoclasm, Suffering-Pleasure) got a coherent grouping Given the ordinal character of data, the analysis was developed by means of a polichoric correlations matrix (Jöreskog, 2005). The orthogonal rotation method known as Varimax was employed due to it allows the minimization of the variability in coefficients for each factor. Thus, it reduced the number of components with high loadings in the same variable and simplified the interpretation factor because of the improvement of the extracted solution (Timm, 2002). A Kaiser normalisation criterion was also used, obtaining an appropriate fit and balance between the number of participants and the number of items $\left(\mathrm{KMO}=.798\right.$; Bartlett's Sphericity Test: $\mathrm{X}^{2}=$ $2782.4 \mathrm{gl} ; 435 \mathrm{sig}<.01$ ). Besides, every item with charges under.40 in a single factor was eliminated (Nunnally \& Bernstein, 1994), while those with simultaneous loadings over .40 in two or more dimensions were also supressed (Vallejo, 1992).

The six isolated components explained $45.4 \%$ of the total variance (Factor 1 explained 9.8\%; Factor 2, 8.2\%; Factor 3, 7.2\%; Factors 4 and 5 explained $6.8 \%$ each, and Factor 6, 6.6\%). Under these circumstances 30 of the 92 under analysis were maintained (Table 3 ).

Inspecting the new structure now isolated, it is observed that 4 of the 30 original items -taken for this step of the analysis- charged in a different factor with respect to that for which they were initially designed (Table 4).

A comprehensive reading of items content indicated coherence between them and their charges.
Furthermore, items 2, 25 and 79, which were charged in different components with respect of those for which they were originally created, were exactly the same objected by judges, classifying them in the very similar way -it must be noticed that in that step they were identified as 77,36 and 25 , respectively, because of the mentioned change of numbers due to elimination process (Table 2).

Taking into account the measurement level planned to answer the items, internal consistency for each dimension was examined by calculating an ordinal Alpha coefficient departing from polychoric correlations, intending to avoid possible underestimations (Elosua \& Zumbo, 2008; Gadermann, Guhn \& Zumbo, 2012). Factor 1 obtained a .82 index; Factor 2, .81; Factor 3, .80. Factor 4, .76; Factor 5, .79 and Factor 6, .77.

\subsubsection{Confirmatory Factorial Study}

The isolated structure in the exploratory study was tested later by a confirmatory factor analysis (Figure 1). Considering the ordinal character of the observed variables, a robust methodology, including the use of a polychoric correlations matrix to calculate the respective covariance matrix, was the call. In the other hand, and also in view of those ordinal responses, a free asymptotic estimation method weighted least squares (WLS) - was the proper way to proceed. It should be noted that while the application of this statistic procedure allows processing a greater number of variables and minimizing errors of convergence and infringing equations as well (Forero, Maydeu \& Gallardo, 2009; Jöreskog \& Sörbom, 1999; Yuan, Wu \& Bentler, 2011), it also requires a wide enough sample $(n \geq 800)$ when the number of variables in analysis will be higher than 15, also possessing a polytomous response (Boomsma, 2000).

The model fit was tested using diverse goodness of fit indices as it was recommended by several authors (e.g. Holgado Tello, Chacón, Barbero \& Vila, 2010; Jöreskog \& Sörbom, 1999; Kline, 2005). Thus, X2, GFI (Goodness of Fit Index), AGFI (Adjusted Goodness of Fit Index) and RMSEA (Root Mean Square Error of Approximation) were considered (Schumacker \& Lomax, 2004).

As seen in Table 5, the empirical model extracted in the exploratory phase presented acceptable values. GFI and AGFI indices were placed over .90, minimal value accorded as cut-off point of a good fit versus a mediocre one (Byrne, 1998; Kelloway, 1998). 
R E S E A R C H

Table 3. Paradoxical Personality Scale. 6-Factor Solution for Exploratory Factor Analysis.

\section{ITEMS}

\section{Suffering \\ - Pleasure}

(F1)

Soy una persona que ante la

05 menor cosa negativa sufro, y ante la menor cosa positiva me alegro.

Creo ser una persona muy

07 sensible y susceptible a experimentar placer y dolor.

Cuando realizo mis actividades, muchas veces me invade una gran satisfacción y olvido mis preocupaciones, pero en ocasiones el sufrimiento se acrecienta.

Tengo momentos de gran

38 melancolía que suelen saltar hacia momentos de gran felicidad.

Cuando las cosas no me salen suelo sufrir bastante $y$

47 permanecer inmóvil, pero a veces, por el contrario, tomo mayor energía y lo afronto.

Soy muy susceptible a

56 experimentar placer cuando se me elogia, y gran sufrimiento cuando se me critica.

A menudo experimento el

70 sufrimiento y el placer con gran facilidad.

Por momentos hago muchas

29 cosas a la vez, y por momentos no hago nada.

Soy una persona que puede

44 pasar largas horas en actividad, pero que a la vez le gusta dormir otra buena cantidad de tiempo.

Suelo dedicar gran cantidad de energía a mis actividades

49 durante períodos de tiempo extensos, y posteriormente tomo prolongados descansos.

Tengo por costumbre dedicar

52 tiempo al ocio luego de haber trabajado mucho.

\section{0,67}

0,48

0,68

0,51

0,65

0,61

0,65 
R E S E A R C H

\section{ITEMS}

Dedico grandes períodos de tiempo a la

58 reflexión y al ocio, para luego poder trabajar arduamente por grandes lapsos de tiempo.

Puedo permanecer atento y concentrado

81 durante mucho tiempo, y disperso y desconcentrado durante otro.

Creo poder concentrarme cuando lo

88 necesito, sin embargo cada tanto me distraigo con facilidad.

02 Generalmente soy bastante tímido, pero por momentos soy bastante atrevido.

En ciertas circunstancias soy una persona

31 muy introvertida, pero en otras soy muy extrovertida.

En ciertas reuniones suelo quedarme

42 callado, pero en otras suelo ser muy participativo.

Estando en reuniones suelo enfrascarme en

57 mí mismo e ignorar a las demás personas, pero a veces soy muy participativo.

Soy una persona con muchas ideas

32 fantasiosas, pero que no siempre se deja llevar por ellas.

Suelo tener ideas muy fantasiosas con poca

48 aprobación, e ideas muy corrientes con mucha aceptación.

Por momentos intento crear nuevas realidades, pero otras veces prefiero quedarme cómodo en esta realidad preexistente.

Tengo producciones novedosas que suelen

86 adaptarse a la realidad, aunque otras veces no se ajustan tanto.

Me siento seguro siendo tradicional, pero sé

23 que a veces es bueno probar cosas diferentes.

Suelo ser consciente de la importancia del aporte previo de otras personas a mis actividades, aunque otras veces creo que mis logros son solo gracias a mi esfuerzo.

Suelo explorar nuevas ideas mediante

25 ensayo y error, aunque a veces prefiero hacer las cosas del modo más conocido y estándar posible.

$\begin{array}{cccccc}\text { Suffering } & \text { Hyperactivity } & \text { Extroversion } & \text { Imagination- } & \text { Conservatism } & \text { Humility } \\ \text { Pleasure } & \text {-Hypoactivity } & \text {-Introversion } & \text { Reality (F4) } & \text { Iconoclasm } & \text { - Pride } \\ \text { (F1) } & \text { (F2) } & (\mathrm{F} 3) & & (\mathrm{F} 5) & (\mathrm{F} 6)\end{array}$

0,54

0,47

0,48

0,64

0,77

0,42

Hoffmann, de la Iglesia, Stover and Fernández (2014) | int.j.psychol.res. 7 (1) | PP. 49 - 72 


\section{ITEMS}

Creo ser una persona bastante tradicional,

28 aunque a veces me gusta hacer cosas fuera de lo común.

Trato de no alejarme de los

68 convencionalismos por temor al fracaso, pero en ocasiones tomo coraje y emprendo actividades innovadoras.

En determinadas ocasiones soy una

76 persona bastante autocrítica, y a veces me comporto un poco arrogante.

En ciertas circunstancias me siento superior

79 a los demás, pero en otras me siento demasiado inferior.

A veces me comporto como una persona

80 muy competitiva pero, en ciertas ocasiones, soy bastante cooperativo.

\begin{tabular}{|c|c|c|c|c|c|}
\hline $\begin{array}{l}\text { Suffering } \\
\text { Pleasure } \\
\text { (F1) }\end{array}$ & $\begin{array}{c}\text { Hyperactivity } \\
\text {-Hypoactivity } \\
\text { (F2) }\end{array}$ & $\begin{array}{l}\text { Extroversion } \\
\text {-Introversion } \\
\text { (F3) }\end{array}$ & $\begin{array}{l}\text { Imagination- } \\
\text { Reality (F4) }\end{array}$ & $\begin{array}{l}\text { Conservatism } \\
\text { - Iconoclasm } \\
\text { (F5) }\end{array}$ & $\begin{array}{l}\text { Humility } \\
\text { - Pride } \\
\text { (F6) }\end{array}$ \\
\hline
\end{tabular}

0,72

0,45

Table 4. Paradoxical Personality Scale. Items charged in different dimensions regarding the original design.

\section{ITEMS}

02

Generalmente soy bastante tímido, pero por momentos soy bastante atrevido.

Suelo ser consciente de la importancia del aporte previo de

21 otras personas a mis actividades, aunque otras veces creo que mis logros son solo gracias a mí esfuerzo.

Suelo explorar nuevas ideas mediante ensayo y error,

25 aunque a veces prefiero hacer las cosas del modo más conocido y estándar posible.

79

En ciertas circunstancias me siento superior a los demás, pero en otras me siento demasiado inferior.
Original Dimension Dimension where it charges

Humility - Pride Extroversion - Introversion

Humility - Pride Conservatism - Iconoclasm

Responsibility Irresponsibility

Conservatism - Iconoclasm

Rationality - Intuition

Humility - Pride
As for RMSEA, it can be valued as achieving a good fit since patterns vary form 0 to .08 (Lévy \& González, 2006).

These good results were accompanied with the absence of infringing equations (Heywood cases and standardized parameters higher than1), which is a warranty for a better fit model since it has been theoretically and empirically identified, which assures more coherence between the observed and the underlying variables (Oliver, Tomás \& Hontangas, 1999; Varela, Abalo, Rial \& Braña, 2006).

All estimated parameters -from items to latent variables, as well as covariances within factors - were statistically significant $(p<.05)$. Regarding estimations corresponding to items, determination coefficients $\left(R^{2}\right)$ were calculated for each of them. These procedures permitted to establish the explained percentage of variance for each item referred to the corresponding underlying variable. A minimal value of $\mathrm{R}^{2}=.50-$ equivalent to the $50 \%$ of explained variance was established for interpretation (Kline, 2005). Table 6 shows that only half the items overcame such value, while the other half stayed under that limit.

Covariances within the model dimensions were examined in terms of their value as possible evidences of convergent and discriminant validity. The rank between .50 and .85 was considered as desirable to pose factor independence. Hence, values over .85 were taken as indicators of evidences of convergent validity between factors, which suggests the possibility of merging both variables into one. Values under.50 were interpreted as discriminant validity evidences, 
R E S E A R C H

Figure 1. Paradoxical Personality Scale. Model extracted in the exploratory study.

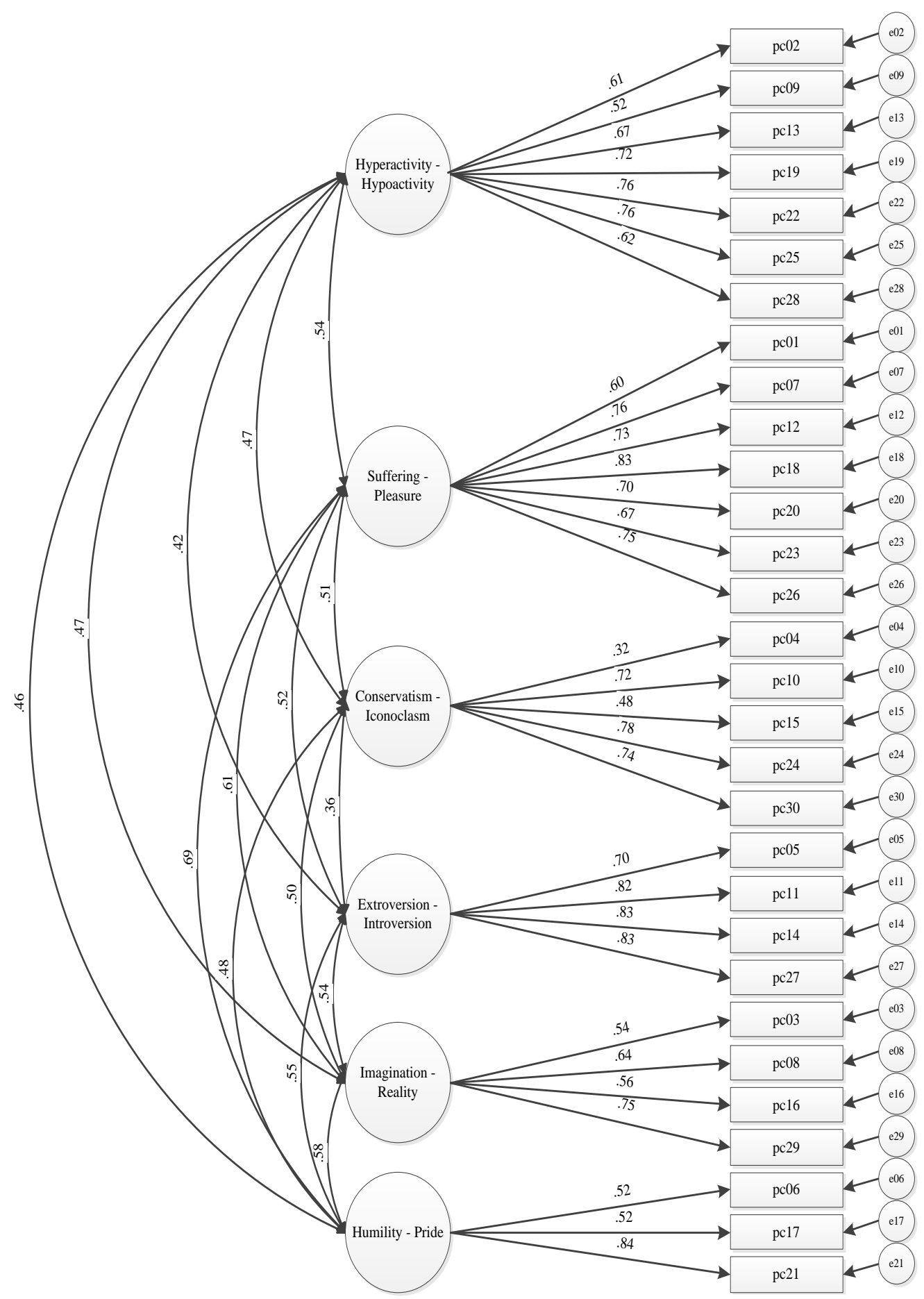

Note. Items randonmly numbered from 1 to 30 , departing from resulting items after exploratory study. Changes in the sequence are due to elimination process. 
R E S E A R C H

Table 5. Paradoxical Personality Scale. Model fit for exploratory study.

\begin{tabular}{|cc}
\multicolumn{3}{c}{ Goodness of fit indices } \\
\hline X2 & $2134.42^{* *}$ \\
\hline GI & 390 \\
GFI & .94 \\
AGFI & .93 \\
\hline RMSEA [IC] & $.074[.071-.077]$ \\
\hline
\end{tabular}

Table 6. Determination coefficients for items.

\begin{tabular}{|c|c|c|c|c|c|}
\hline Item & $\mathrm{R}^{2}$ & Item & $\mathrm{R}^{2}$ & Item & $\mathrm{R}^{2}$ \\
\hline pc01 & 0,36 & pc11 & 0,67 & pc21 & 0,71 \\
\hline pc02 & 0,37 & pc12 & 0,53 & pc22 & 0,58 \\
\hline pc03 & 0,29 & $\mathrm{pc} 13$ & 0,45 & pc23 & 0,46 \\
\hline pc04 & 0,10 & pc14 & 0,69 & pc24 & 0,61 \\
\hline pc05 & 0,49 & pc15 & 0,23 & pc25 & 0,58 \\
\hline pc06 & 0,27 & pc16 & 0,31 & pc26 & 0,56 \\
\hline pc07 & 0,58 & $\mathrm{pc} 17$ & 0,27 & pc27 & 0,69 \\
\hline pc08 & 0,41 & pc18 & 0,69 & pc28 & 0,38 \\
\hline pc09 & 0,27 & pc19 & 0,52 & pc29 & 0,56 \\
\hline pc10 & 0,52 & pc20 & 0,49 & pc30 & 0,55 \\
\hline
\end{tabular}

alluding to the alternative of adding dimensions to the model (Rial Boubeta, Varela Mallou, Abalo Piñeiro \& Lévy Mangin, 2006). As Figure 1 lets to appreciate, 9 of the 15 covariances integrating the model were within these reference values -from .85 to .50 - which are sustaining independence among factors, and 6 were under $.50-\mathrm{HH}-\mathrm{Cl}(.47), \mathrm{HH}-\mathrm{El}(.42), \mathrm{Cl}-\mathrm{El}(.36), \mathrm{HH}$ IR (.47), HH-HP (.46) and HP-Cl (.48)-. These values, being close to.50, however, could be taken as evidences of discriminant validity.

\subsection{Test-retest Reliability Study}

The short version resulting from the construct validity analyses described above was later studied related to the temporal stability of scores for every dimension. Correlational study between the first and the second data gathering from the same sample obtained acceptable and significant results $(p<.01)$ although not optimal for every scale- .84 for Factor 1 (Hyperactivity-Hypoactivity), .60 for Factor 2 (Suffering-Pleasure), .70 for Factor 3 (ConservatismIconoclasm), .73 for Factor 4 (Extroversion-
Introversion), and .64 for Factor 5 (ImaginationReality) and 6 (Humility-Pride).

\section{DISCUSSION}

Analysing those 150 items developed to assess the 10 theoretical dimensions composing paradoxical personality proposed by Csikszentmihalyi (1996) allowed to report a final structure that was reduced to 6 latent variables (HyperactivityHypoactivity, Imagination-Reality, ExtroversionIntroversion, Humility-Pride, ConservatismIconoclasm, Suffering-Pleasure), represented by a pool of 30 items. Despite of this loss of items, the indices obtained show acceptable psychometric qualities concerning the scale.

First of all, in respect to evidences of content and facies validity, the refinement achieved in items deserves a special mention. This process was carried out in two different moments: the initial expert judgement followed by the calculation of Aiken's $V$ coefficients -content validity evidences- and the 
subsequent exam of the remaining items appearance by means of a pilot study to ensure the student's comprehension of sentences as well as their pertinence regarding to specific academic environments -facies validity evidences and linguistic adequeation of items, responses and instructions-. The whole process previously reported enabled to retain just those items with contents valued as the most representative of the universe of behaviors associated to paradoxical personality, which is mandatory condition when a scale is being developed (Aiken, 2003).

As for evidences of construct validity, principal components analysis extracted 6 dimensions with similar percentages of explained variance, which allows to assert an almost equivalent explicative weight for every factor composing the model. Thus, no theoretical predominance could be asserted, being all equivalent factors that explain the concept precisely because of this similarity in percentages of explained variances i.e. it seems reasonable to sustain the hypothesis which asserts that there are not prevalent factors in the model

Moremover, global results of the confirmatory factor analysis verified an adequate fit model in respect to empirical data. It must be remembered that this is an empirical model, isolated -as described- in an exploratory step and confirmed later in a farther phase. In general terms, it can be stated that those dimensions exhibit a clear tendency to independence, even when certain covariance values -while not too far from standard patterns- would indicate the need of adding new latent variables to the model. Besides, every item shows a statistically significant relationship with factors.

Notwithsanding the strong notes mentioned above, there is a series of weak points that must be taken in consideration carefully. They are linked to the theoretical concept, to the analyses developed and to the scale resulting from the study.

Concerning conceptual aspects, it should be recalled that the theoretical basis of this concept is supported in conclusions reached by Csikszentmihalyi (1996) in his studies, which were developed with proffessionals distinguished because of their creativity. Therefore, given that his assertions were derived from a population different fom college students, it does not seem unusual that some of the dimensions here examined are missing -Rationality/ Intuition, Responsibility/ Irresponsibility, Masculinity/ Femininity and Objectivity/ Subjectivity-. As the author emphasizes, not each component integrated in the model has an actual manifestation in each individual, which opens the possibility of contemplating some other dimensions omitted in his research. Regarding the factors retained in the analyses, it is interesting to point out that 6 of the 15 covariances are under the established limit of .50 , which supports the hypothesis of independence for these factors- Hyperactivity/ Hypoactivity - Conservatism/ Iconoclasm (.47), Hyperactivity/ Hypoactivity- Extroversion/ Introversion (.42), Conservatism/ Iconoclasm-Extroversion/ Introversion (.36), Hyperactivity/ Hypoactivity Imagination/ Reality (.47), Hyperactivity/ Hypoactivity Humility/ Pride (.46) and Humility/ Pride Conservatism/ Iconoclasm (.48). This closeness of values to the cut-off point would be an indicator of certain tendency to independence although it is mandatory to examine it in wider samples: due to these limit-values, the possibility that factors could be non-independent cannot be discarded. Thus, the fit of the model here proposed must be evaluated observing the fit of another second-order model capable of assemble those dimensions.

Viewing the analyses carried out, the first limitation observed corresponds to the sample size in the confirmatory factor analysis. That fact precludes a cross validation study since splitting the sample $(n=800)$ into halves would produce convergence errors in covariance matrices. Besides, despite every estimated parameter presents significant associations, some of these values are beyond expected patterns. Within them half of items which do not reach acceptable values $\left(R^{2}>.50\right)$ can be identified, which is associated with the percentage of variance whith each of them contributes to explain in its respective dimension. As mentioned before, indicators of discriminant validity were found in the case of 6 covariaces (values under .50). However, all of them show the tendency to reach de value of .50 , being this the minimum accepted to assert the independence of factors (Rial, Varela, Abalo \& Lévy, 2006). Both weaknesses could be severely affected by the sample size; this difficulties will be corrected in future developments, by adding new cases in order to improve estimated parameters fit, an to develop cross validation studies within groups. And finally as concerning to reliability analyses on the dimensions, internal consistency indices for Factors 1,2 and 3 were acceptable $(.82, .81$ and .80 , respectively). Though values for Factors 4,5 and 6 were slightly inferior (.76, .79 and .77), but also admissible facing the small number of items retained composing those factors. It is also interesting to note that the values obtained by the test-retest procedure, except for Factor 1 (.84), were far of being optimal $(r>.80)$. Thus, underestimations for factors $2,3,4,5$ and 6 , whose values varied from .60 to .75 , could be attributed to the 
period between examinations (30 days) as well as to the complexity inherent to the concept since paradoxical personality, defined as a dimension of creativity, does not remain unaltered in time. This possible change must be investigated as well.

In relation to the complex character of the concept, this note adds some complications when it must be operativized into indicators: contradictory traits corresponding to paradoxical personality introduce violations in two classic guidelines proposed when psychometrical items must be redacted. The first standard suggests the suppression of sentences containing two opposite propositions in order to belittle ambiguity. The second foregrounds the use of short sentences to avoid fatigue in examinees (Likert, 1932; Moreno, Martínez \& Muñiz, 2004; Thurstone, 1928). Following this reasoning, as it was reported in a previous research, this methodological weakness must be properly pondered (Freiberg Hoffmann, 2012). The intentional non-compliance of both rules priors the idea that states indicators (items) development must represent accurately the kind of behavior to be assessed (Aiken, 2003; Martínez, 2005). Consequently, pursuing the goal of describing a paradoxical behavior, avoiding sentences implying opposite polarities at the same time seems to be utopical. Thereby, it is supposed that this type of propositions could generate more comfort in those individuals who possess this attribute in an important degree and hence feeling more identified with them. On the contrary, those with such traits less accentuated will experience more discomfort facing the ambiguity of sentences, and then feeling less identification with that paradoxical coexistence.

Observing assertions above it seems sensible to ask if such complex design of items could be causing their movements from one dimension to another, movement first produced because of the expert judgement and reinforced later by the exploratory factor study. That fact forces considerations referred to possible mistakes in item redaction such as inconsistencies -different from those inherent to the concept-, or perhaps to conjecture that items could be responding simultaneously to both dimensiones (the original one and that declared by judges), resulting in the possibility of merging them in one. Nevertheless, this last possibility will be promptly discarded since the analysis of evidences of convergent validity performed in occasion of the confirmatory factor study have verified the independence of latent variables.

As described formerly, studying creative personality through its paradoxical character involves several issues which require a deeper analysis of the concept. This research have intended its empirical measurement by means of indicators composing a self-report, while that concept have been so far theoretically described departing from case studies. The ultimate goal of this research line consists in testing evidences of validity for that model. The resulting scale, adapted from a linguistic standpoint to local idioms and with adequate psychometric properties, obliges to new analyses before its employment in the professional field. This is to ensure more certainty to potential users. For instance, the replication of these studies in wider new samples seems mandatory, as well as the development of criterion validity studies. It seems relevant to highlight the multiplicity of issues that the complex character of creativity imposes to its operativization, generating a huge criticism. The lack of an unanimous definition must be taken into account (Laime, 2005), following with the consequential problem to establish convergent and discriminant validity evidences. The arduousness involved in predicting this phenomenon due to the diversity of processes and source materials implied, also deserves a remark. In the other hand its erratic and capricious manifestation raises another problem since it would produce different measures from the same person in short periods (Romo, 1997). All these limitations suffered by every instrument to assess any aspect of creativity are determined mainly by the multicomponential character of the concept and affect every related dimension, including personality.

Finally, worth mentioning that creativity, as a trainable ability, has assumed currently an important role because it is considered an adequate ability to configure the types of adaptipe behavior regarding dynamics proposed by a globalized world. For this reason, analising its multiple dimensions -person, process, product, environment- (e.g. Csikszentmihalyi, 1996; de la Torre, 2006; Gardner, 1997; Pascale, 2005; Simonton, 2003) seems to be valuable, intending to provide more accurate measures.

It is expected to go on examining the design of the scale here introduced in order to overcome the limitations detailed before by means of future developments and improving its metrical quality by carrying out studies on criterion validity evidences concerning academic achievement in students from diverse careers, within some other variables of interest in the field. Finally, the possibility of deepening in the pertinence referred to the model content in our local milieu is taken as a goal to be accomplished. It is also possible to propose different indicators to measure the concept empirically when exploring the factibility of including new dimensions which could be more appropriate to our collge students' profile. 
Given that, the ability to apply new solutions to problems of specific disciplines depends on the type of instruction received (Csikszentmihalyi, 1996), colleges interested in the incorporation of creativity training to their curricula could find in Paradoxical Personality Scale a helpful device to diagnose particular profiles, in order to design specific programs for every case.

\section{ACKNOWLEDGMENTS}

This paper presents partial outcomes of a
study corresponding to a a PhD
fellowship, and it is framed in a major research which
accounts a a
University of Buenos Aires.

\section{REFERENCES}

Aiken, L.R. (1985). Three coefficientsfor analyzing the reliability and validity of ratings. Educational and Psychological Measurement, 45, 131-142.

Aiken, L. R. (2003). Tests Psicológicos y Evaluación (10a ed.). Naucalpan de Jñuarez, México: Pearson.

Almansa Martínez, P., \& López Martínez, O. (2010). ¿Existe relación entre creatividad y preferencia estilística en un grupo de alumnos de enfermería? Anales de Psicología, 26(1), 145-150.

Batey, M., Chamorro Premuzic, T., \& Furnham, A. (2010). Individual differences in ideational behavior: Can the big five and psychometric intelligence predict creativity scores? Creativity Research Journal, 22(1), 90-97.

Benlliure, V. A. (2006). Evaluar aspectos de la personalidad. En S. d. Torre, y S. Violant, Comprender y evaluar la creatividad. Vol II (pp.303-323). Málaga: Aljibe.

Byrne, B.M. (1998). Structural Equation Modeling with LISREL, PRELIS and SIMPLIS. London: Lawrence Erlbaum Associates, Inc.

Boomsma, A. (2000). Reporting analyses of covariance structures. Structural Equation Modeling, 7(3), 461-483.

Chacón Araya, Y., \& Moncada Jiménez, J. (2006). Relación entre personalidad y creatividad en estudiantes de Educación Física. Actualidades Investigativas en Educación, 6(1), 1-19.

CEPAL (Comisión Económica para América Latina y el Caribe) (2011). Educación desarrollo y ciudadanía en América Latina. Santiago: CEPAL.
Clapham, M. M. (2004). The convergent validity of the Torrance test of creative thinking and creativity interests inventories. Educational and Psychological Measurement, 64, 828-841.

Csikszentmihalyi, M. (1996). Creatividad. Barcelona: Paidós.

Davis, G. A. (1989). Testing of creative potential. Contemporary Educational Psychology, 14, 257-274.

De la Torre, S. (2006). Creatividad en la educación. En S. de la Torre \& V. Violant, Comprender y evaluar la creatividad. Vol.I (pp. 309-322). Málaga: Aljibe.

Elisondo, R. C., \& Donolo, D. S. (2010). ¿Creatividad 0 inteligencia? That is not the question. Anales de Psicología, 26(2), 220-225.

Elosua Oliden, P., \& Zumbo, B. D. (2008). Coeficientes de fiabilidad para escalas de respuesta categórica ordenada. Psycothema, 20(4), 896-901.

Esfahani, A. N., Ghafari, M., Emami, A. R., \& Baboli, A. (2012). Studying impacts of personality traits on creativity (Case study: University of Isfahan's students). Journal of Basic and Applied Scientific Research, 2(4), 3457-3460.

Eysenck, H. J. (1995). Genius. The natural history of creativity. New York: Cambridge University Press.

Feist, G. J. (1998). A meta-analysis of personality in scientific and artistic creativity. Personality and Social Psychology Review, 2(4), 290-309.

Forero, C.G., Maydeu Olivares, A., \& Gallardo Pujol, D. (2009). Factor analysis with ordinal indicators: A Monte Carlo study comparing DWLS and ULS estimation. Structural Equation Modeling, 16, 625-641.

Freiberg Hoffmann, A. (2012, noviembre). Estudio de contenido de los reactivos de un instrumento para la evaluación de la personalidad creativa. Trabajo presentado en el IV Congreso Internacional de Investigación y Práctica Profesional en Psicología. XIX Jornadas de Investigación. VIII Encuentro de Investigadores en Psicología del Mercosur. Facultad de Psicología, Universidad de Buenos Aires.

Gadermann, A. M., Guhn, M., \& Zumbo, B. D. (2012). Estimating ordinal reliability for Likert-type and ordinal item response data: A conceptual, empirical, and practical guide. Practical Assessment, Research \& Evaluation, 17(3), 113.

Gardner, H. (1997). Arte, Mente y Cerebro. Barcelona: Paidós. 
Getzels, J. W., \& Jackson, P. W. (1962). Creativity and Intelligence: Explorations with gifted students. New York: Wiley.

Giovacchini, P. L. (1991). The creative person as maverick. Journal of the American Academy of Psychoanalysis, 19(2), 174-188.

Gorsuch, R. L. (1983). Factor Analysis. New Jersey: LEA.

Guilford, J. P. (1950). Creativity. The American Psychologist, 5(9), 444-454.

Guilford, J. P. (1977). La naturaleza de la inteligencia humana. Buenos Aires: Paidós.

Haller, C. S., \& Courvoisier, D. S. (2010). Personality and thnking styles in different creative domains. Psychology of Aesthetics Creativity and the Arts, 4(3), 149-160.

Hatcher, L. (1994). A step by step approach to using the SAS system for factor analysis and structural equation modeling. Cary, NC: SAS Institute.

Helson, R. (1996). In search of the creative personality. Creativity Research Journal, 9(4), 295-306.

Holgado Tello, F., Chacón Moscoso, S., Barbero García, I., \& Vila Abad, E. (2010). Polychoric versus Pearson correlations in exploratory and confirmatory factor analysis of ordinal variables. Quality \& Quantity, 44(1), 153-166.

IBM Corporation (2012). IBM SPSS Statistics (21). Retrieved from http://www01.ibm.com/software/es/analytics/spss/

Jöreskog, K. G. (2005). Structural equation modeling with ordinal variables using LISREL. Retrieved from http://www.ssicentral.com/lisrel/techdocs/o rdinal.pdf

Jöreskog, K.G., \& Sörbom, D. (1999). LISREL 8: user's reference guide. Lincolnwood, IL: Scientific Software International, Inc.

Karwowski, M. (2012). Did curiosity kill the cat? Relationship between trait curiosity, creative self-efficacy and creative personal identity. Europe's Journal of Psychology, 8(4), 547558.

Kaufman, J. C. (2009). Beyond big and little: The four C model of creativity. Review of General Psychology, 13(1), 1-12.

Kelloway, E. K. (1998). Using LISREL for structural equation modeling. Thousand Oaks: Sage Publications.

Kline, R. B. (2005). Structural equation modeling. New York: Guilford Press.
Laime Pérez, M. C. (2005). La evaluación de la creatividad. LIBERABIT, 11, 35-39.

Lévy Mangin, J. P., \& González, N. (2006). Modelización y Causalidad. En: J.P. Lévy Mangin \& J. Varela Mallou (Eds.), Modelización con estructuras de covarianzas en ciencias sociales (pp. 155-175). Coruña: Netbiblo.

Likert, R. (1932). A technique for the measurement of attitudes. Archives of Psychology, 140, 1-50.

Limiñana Gras, R. M., Corbalán Berna, J., \& Sánchez López, M. P. (2010). Creatividad y estilos de personalidad: Aproximación a un perfil creativo en estudiantes universitarios. Anales de Psicología, 26(2), 273-278.

López Martínez, O. L., \& Brufau, R. M. (2010). Estilos de pensamiento y creatividad. Anales de Psicología, 26(2), 254-258.

López, O., Corbalán, F. J., \& Martínez, F. (2006). Instrumentos y medidas clásicas de la creatividad. En S. de la Torre \& V. Violant, Comprender y evaluar la creatividad. Vol.II (pp. 213-236). Málaga: Aljibe.

Lorenzo Seva, U., \& Ferrando, P. J. (2012). Manual of the Program FACTOR. Retrieved from http://psico.fcep.urv.es/utilitats/factor/

Lowenfeld, V. (1979). El desarrollo de la capacidad creadora. Buenos Aires: Kapelusz.

Manzano Patiño, A., \& Zamora Muñoz, S. (2009). Sistema de ecuaciones estructurales: una herramienta de investigación. Cuaderno técnico 4. Centro Nacional de Evaluación para la Educación Superior A.C. Retrieved from http://www.senasica.gob.mx/includes/asp/dow nload.asp? iddocumento $=23068$ \&idurl $=45367$

Martínez Arias, R. (2005). Psicometría: teoría de los tests psicológicos y educativos. Madrid: Síntesis.

Martinsen, O. L. (2011). The creative personality: A synthesis and development of the creative person profile. Creativity Research Journal, 23(3), 185-202.

Maslow, A. (1973). El hombre autorrealizado. Barcelona: Kairós.

Mayans, I. M., \& Tubella Casadeval, I. (2005). Cultura, identidad y globalidad: La cultura y las culturas en la sociedad del conocimiento. En I. Tubella Casadeval \& J. Vilaseca Requena, Sociedad del conocimiento. (pp. 119-150). Barcelona: UOC.

McMullan, W. E. (1976). Creative individuals: Paradoxical personajes. The Journal of Creative Behavior, 10(4), 265-275. 
Merino Soto, C., \& Livia Segovia, J. (2009). Intervalos de confianza asimétricos para el índice la validez de contenido: un programa Visual Basic para la $\mathrm{V}$ de Aiken. Anales de Psicología, 25(1), 169-171.

Merrotsy, P. (2013). Tolerance of ambiguity: A trait of the creative personality? Creativity Research Journal, 25(2), 232-237.

Ministerio de Educación, Secretaría de Políticas Universitarias. (2011). Anuario 2011. Estadísticas Universitarias. Retrieved from http://informacionpresupuestaria.siu.edu.ar/Do cumentosSPU/Anuario\%20de\%20Estad\%C3

$\%$ ADsticas\%20Universitarias\%20-

\%20Argentina\%202011.pdf

Moreno Bayardo, M. G. (2000). Introducción a la Metodología de la Investigación Educativa 2. México, D.F.: Editorial Progreso.

Moreno, R., Martínez, R., \& Muñiz, J. (2004). Directrices para la construcción de ítems de elección múltiple. Psicothema, 16(3), 490-497.

Naderi, H., Abdullah, R., Aizan, H. T., Sharir, J., \& Kumar, V. (2010). Relationship between creativity and academic achievement: A study of gender differences. Journal of American Science, 6(1), 181-190.

Nieto Martín, S., \& Rodríguez Conde, J. M. (2010). Investigación y Evaluación Educativa en la Sociedad del Conocimiento. Salamanca: Ediciones Universidad de Salamanca.

Nunnally, J. C., \& Bernstein, I. H. (1994). Psychometric Theory (3rd ed.). New York: McGraw-Hill.

Oliver, A., Tomás, J. M., \& Hontangas, P. M. (1999). Efecto del número de indicadores por factor sobre la identificación y estimación en modelos aditivos de análisis factorial confirmatorio. QÜESTIIO, 23(2), 239-259.

Pascale, P. (2005). ¿Dónde está la creatividad? Una aproximación al modelo de sistemas de Mihaly Csikszentmihalyi. Arte Individuo $y$ Sociedad, 17, 61-84.

Pérez Fabello, M. J., \& Campos, A. (2007). Creatividad y rendimiento académico de los estudiantes de bellas artes. Revista Galego Portuguesa de Psicoloxía e Educación, 15(2), 127-133.

Pervin, L. A., \& John, O. P. (2000). Personalidad: Teoría e Investigación. México, D.F.: El Manual Moderno.

Rial Boubeta, A., Varela Mallou, J., Abalo Piñeiro, J., \& Lévy Mangin, J. P. (2006). El Análisis Factorial Confirmatorio. En: J.P. Lévy Mangin \& J. Varela Mallou (Eds.), Modelización con estructuras de covacianzas en ciencias sociales (pp. 119-154). Coruña: Netbiblo.

Richaud de Minzi, M. C. (2005). Desarrollos del análisis factorial para el estudio de ítem dicotómicos y ordinales. Revista Interdisciplinaria, 22(2), 237-251.

Rogers, C., \& Freiberg, H. J. (1996). Libertad y Creatividad en la Educación (3a. ed.) Barcelona: Paidós.

Romo, M. (1997). Psicología de la creatividad. Barcelona: Paidós.

Runco, M. A., \& McGarva, D. J. (2013). Creativity and motivation. En S. Kreitler (ed.), Cognition and motivation: Forging and interdisciplinary perspective. (pp. 468-482). New York: Cambridge University Press.

Sanz de Acedo Baquedano, M. T., \& Sanz de Acedo Lizarraga, M. L. (2012). A correlational and predictive study of creativity and personality of college students. The Spanish Journal of Psychology, 15(3), 1081-1088.

Schumacker, R. E., \& Lomax, R. G. (2004). A beginner's guide to estructural equation modeling (2a ed.). New Jersey, London: Lawrence Erlbaum Associates.

Scientific Software International (2006). LISREL (8). Retrieved from http://www.ssicentral.com/lisrel/resources.html

Simonton, D. K. (2003). Scientific creativity as constrained stochastic behavior: the integration of product, person, and process perspectives. Psychological Bulletin, 129(4), 475-495.

Sternberg, R. (2006). Creating a view of creativity: The first 25 years. Psychology of Aesthetics, Creativity, and the Arts, S(1), 2-12.

Thurstone, L. L. (1928). Attitudes can be measured. American Journal of Sociology, 33, 529-554.

Timm, N.H. (2002). Applied Multivariate Analysis. New York: Springer.

Torrance, E. P. (1966). Torrance Test of Creative Thinking. Lexington, MA: Personnel Press.

Treffinger, D. J., \& Selby, E. C. (2008). Comprendiendo y desarrollando la creatividad: Una aproximación práctica. Revista de Psicología, 26(1), 7-21.

UNESCO (Organización de las Naciones Unidas para la Educación, la Ciencia y la Cultura) (1998, octubre). Informe Final. Presentado en la Conferencia mundial sobre la educación superior. La educación superior en el siglo XXI. Visión y acción. París. Retrieved from http://unesdoc.unesco.org/images/0011/00116 3/116345s.pdf 
Vallejo Seco, G. (1992). Análisis Multivariantes Aplicados a las Ciencias del Comportamiento. Oviedo: Universidad de Oviedo.

Varela Mallou, J., Abalo Piñeiro, J., Rial Boubeta, A., \& Braña Tobio, T. (2006). Análisis Factorial Confirmatorio de Segundo Nivel. En: J. P. Lévy Mangin \& J. Varela Mallou (Eds.), Modelización con estructuras de covarianzas en ciencias sociales (pp. 239-253). Coruña: Netbiblo.

Yuan, K., Wu, R., \& Bentler, P. (2011). Ridge structural equation modeling with correlation matrices for ordinal and continuous data. $\mathrm{Br} J$ Math Stat Psychol. doi: 10.1348/000711010X497442

(4) Hoffmann, de la Iglesia, Stover and Fernández (2014) | int.j.psychol.res. 7 (1) | PP. 49 - 72 


\section{APPENDICES}

Appendix 1: Preliminary translation of items presented in Table 2 into English (not being tested or validated)

\section{Items in Spanish}

18. Siento que soy bastante autosuficiente, aunque reconozco que por momentos necesito pedir ayuda por cuestiones que escapan a mi conocimiento.

20. Muchas veces me apego por completo a las normas, pero muchas otras las transgredo.

25. En ciertas circunstancias me siento superior a los demás, pero en otras me siento demasiado inferior.

28. Cuando tengo que resolver algún problema suelo usar tanto ideas que ya he adquirido, como ideas nuevas que fluyen por mis pensamientos.

29. Suelo aferrarme fuertemente a ciertas ideas mías y suelo dejar ir otras.

32. Suelo ser, en ocasiones, bastante conservador en la realización de algunas actividades y muy arriesgado en otras.

36. Suelo explorar nuevas ideas mediante ensayo y error, aunque a veces prefiero hacer las cosas del modo más conocido y estándar posible.

42. Cuando se me mete una idea en la cabeza por más disparatada que parezca insisto mucho hasta conseguir aplicarla.

43. Cuando tengo que hacer algo me olvido del tiempo pero siempre lo termino.

44. Si bien no me importa cuánto tardo en terminar una actividad, debo confesar que suelo trabajar hasta altas horas de la noche.

52. Por momentos intento crear nuevas realidades, pero otras veces prefiero quedarme cómodo en esta realidad preexistente.

59. Mi lectura de la realidad si bien muchas veces me lleva por caminos equivocados, muchas otras veces me llevan a prever hechos relevantes.

77. Generalmente soy bastante tímido, pero por momentos soy bastante desdeñoso.

104. Si bien me suelo preocupar por mi entorno muchas veces me centro sobre mi persona.

144. Suelo molestarme muy fácilmente, aunque en determinadas circunstancias soy extremadamente tolerante.
Items in English

I feel I am quite self-sufficient, though I admit that sometimes I need to ask for help because of subjects which are beyond my knowledge.

I am very often attached to rules, but also very often I transgress them.

Sometimes I feel superior to other people, but some other times I feel I am too much inferior.

When I need to solve any problem, I use to employ ideas already acquired, as well as new ideas which flow through my thoughts

I use to cling tightly to some of my ideas, and I also use to let go some others.

Occasionally, I use to be quite conservative when developing certain activities, and very risky in some other times.

I use to explore new ideas by means of trial and error, although sometimes I prefer doing things in the most familiar and standard way as possible.

When some idea imposes, I insist a lot till I put it in practice, no matter how much crazy it could seem.

When I have to do something I lose the notion of time, but I always finish that task.

Although I do not care how long it takes to finish some activity, I admit I use to work late at nights.

Sometimes I try to create new realities, but some other times I prefer to stay comfortably in the actual reality.

While my interpretation about reality makes me take wrong ways, many other times let me preview relevant facts.

I am usually pretty shy, but sometimes I am quite contemptuous.

Though I do not use to worry about people around me, I am often self-centred.

I get upset easily (mad), though in some circumstances I am extremely tolerant. 
Appendix 2: Preliminary translation of items presented in Table 2 into English (not being tested or validated)

\section{Items in Spanish}

05. Soy una persona que ante la menor cosa negativa sufro, y ante la menor cosa positiva me alegro.

07. Creo ser una persona muy sensible y susceptible a experimentar placer y dolor.

13. Cuando realizo mis actividades, muchas veces me invade una gran satisfacción y olvido mis preocupaciones, pero en ocasiones el sufrimiento se acrecienta.

38. Tengo momentos de gran melancolía que suelen saltar hacia momentos de gran felicidad.

47. Cuando las cosas no me salen suelo sufrir bastante $y$ permanecer inmóvil, pero a veces, por el contrario, tomo mayor energía y lo afronto.

56. Soy muy susceptible a experimentar placer cuando se me elogia, y gran sufrimiento cuando se me critica.

70. A menudo experimento el sufrimiento y el placer con gran facilidad.

29. Por momentos hago muchas cosas a la vez, y por momentos no hago nada.

44. Soy una persona que puede pasar largas horas en actividad, pero que a la vez le gusta dormir otra buena cantidad de tiempo.

49. Suelo dedicar gran cantidad de energía a mis actividades durante períodos de tiempo extensos, y posteriormente tomo prolongados descansos.

52. Tengo por costumbre dedicar tiempo al ocio luego de haber trabajado mucho.

58. Dedico grandes períodos de tiempo a la reflexión y al ocio, para luego poder trabajar arduamente por grandes lapsos de tiempo.

81. Puedo permanecer atento y concentrado durante mucho tiempo, y disperso y desconcentrado durante otro.

88. Creo poder concentrarme cuando lo necesito, sin embargo cada tanto me distraigo con facilidad.

02. Generalmente soy bastante tímido, pero por momentos soy bastante atrevido.

31. En ciertas circunstancias soy una persona muy introvertida, pero en otras soy muy extrovertida.

\section{Items in English}

Facing the minimal negative event, I suffer, and facing the minimal positive event, I feel happy.

I think I am a very sensitive and susceptible person, when experiencing pleasure and pain.

When I develop my activities, I often feel a huge satisfaction and I leave my worries away, but occasionally suffering begins to increase.

I have moments of melancholy which sometimes change towards moments of great joy.

When I cannot do things well, I use to suffer quite a bit and to freeze, but sometimes, on the contrary, I take hold and I cope with those things.

I am so inclined to experience pleasure when somebody praises me, and a huge suffering when somebody criticises me.

I often experience suffering and pleasure very easily.

Sometimes I do a lot of things at once, and sometimes I do nothing.

I am a person who can spend long time in activity, but who likes to sleep similar periods of time.

I use to spend a big amount of energy in my activities for long periods, and later I take long periods to rest.

I use to spend time in leisure after long periods working.

I spend long periods to reflexion and leisure, to could work hard for long periods after that.

I can stay concentrated and focused during long periods, and dispersed and unfocused by similar periods.

I think I can stay concentrated when I need it; however I am distracted from time to time.

I am generally quite shy, but sometimes I am quite audacious.

Under some circumstances I am very introverted, but sometimes I am very extroverted. 


\section{Items in Spanish}

42. En ciertas reuniones suelo quedarme callado, pero en otras suelo ser muy participativo.

57. Estando en reuniones suelo enfrascarme en mí mismo e ignorar a las demás personas, pero a veces soy muy participativo.

32. Soy una persona con muchas ideas fantasiosas, pero que no siempre se deja llevar por ellas.

48. Suelo tener ideas muy fantasiosas con poca aprobación, e ideas muy corrientes con mucha aceptación.

55. Por momentos intento crear nuevas realidades, pero otras veces prefiero quedarme cómodo en esta realidad preexistente.

86. Tengo producciones novedosas que suelen adaptarse a la realidad, aunque otras veces no se ajustan tanto.

23. Me siento seguro siendo tradicional, pero sé que a veces es bueno probar cosas diferentes.

24. Suelo ser consciente de la importancia del aporte previo de otras personas a mis actividades, aunque otras veces creo que mis logros son solo gracias a mi esfuerzo.

25. Suelo explorar nuevas ideas mediante ensayo y error, aunque a veces prefiero hacer las cosas del modo más conocido y estándar posible.

28. Creo ser una persona bastante tradicional, aunque a veces me gusta hacer cosas fuera de lo común.

68. Trato de no alejarme de los convencionalismos por temor al fracaso, pero en ocasiones tomo coraje y emprendo actividades innovadoras.

76. En determinadas ocasiones soy una persona bastante autocrítica, y a veces me comporto un poco arrogante.

79. En ciertas circunstancias me siento superior a los demás, pero en otras me siento demasiado inferior.

80. A veces me comporto como una persona muy competitiva pero, en ciertas ocasiones, soy bastante cooperativo.

\section{Items in English}

In some social situations I use to remain silent, but in some others I use to participate a lot.

Being in parties or reunions I use to be introspective, ignoring people, but sometimes y participate a lot.

I am a person who has many fanciful ideas, but who not always permits being pulled by them.

I use to have pretty fanciful ideas with very little approval, and so ordinary ideas which are strongly accepted.

Sometimes I try to create new realities, but some other times I prefer to stay comfortably in the actual reality.

I have got novel productions which use to be adapted to reality, though some other times they do not adapt so well.

I feel safe being traditional, but I know that sometimes it is good to try different things.

I use to be aware of the importance of previous contributions from other people to my activities, although some other times I think that my achievements are only due to me.

I use to explore new ideas by means of trial and error, although sometimes I prefer doing things in the most familiar and standard way as possible.

I think I am a very traditional person, although sometimes I like to do things out of the ordinary.

I intend not to get away from conventions because of my fear to failure, but sometimes I take courage and I start with innovative activities

Occasionally I am quite self-criticism person, and sometimes I behave arrogantly.

Sometimes I feel superior to other people, but some other times I feel I am too much inferior.

Sometimes I behave as a very competitive person, but occasionally I am quite helpful. 
R E S E A R C H

\section{Appendix 3: Preliminary translation of items presented in Table 2 into English (not being tested or validated)}

\section{Items in Spanish}

02. Generalmente soy bastante tímido, pero por momentos soy bastante atrevido.

24. Suelo ser consciente de la importancia del aporte previo de otras personas a mis actividades, aunque otras veces creo que mis logros son solo gracias a mi esfuerzo.

25. Suelo explorar nuevas ideas mediante ensayo y error, aunque a veces prefiero hacer las cosas del modo más conocido y estándar posible.

79. En ciertas circunstancias me siento superior a los demás, pero en otras me siento demasiado inferior.

\section{Items in English}

I am generally quite shy, but sometimes I am quite audacious.

I use to be aware of the importance of previous contributions from other people to my activities, although some other times I think that my achievements are only due to me.

I use to explore new ideas by means of trial and error, although sometimes I prefer doing things in the most familiar and standard way as possible.

Sometimes I feel superior to other people, but some other times I feel I am too much inferior.

4 Hoffmann, de la Iglesia, Stover and Fernández (2014) | int.j.psychol.res. 7 (1) | PP. 49 - 72 | 